Magdalena Felcyn-Koczewska*

Nina Ogińska-Bulik

*Instytut Psychologii KUL

** Instytut Psychologii UŁ

\title{
Psychologiczne czynniki sprzyjające wystąpieniu potraumatycznego rozwoju u osób w żałobie
}

\section{Wprowadzenie}

\section{1. Śmierć osoby bliskiej jako doświadczenie traumatyczne}

Śmierć osoby bliskiej to jedno z najczęstszych wydarzeń traumatycznych. Świadczą o tym m. in. badania duńskie (Elk1it, 2002), gdzie najczęściej relacjonowanym doświadczeniem traumatycznym była śmierć kogoś z najbliższej rodziny zgłoszona przez $51,8 \%$ badanych, i amerykańskie, gdzie powodem jednej trzeciej przypadków zespołu stresu pourazowego okazała się niespodziewana śmierć kogoś ważnego (C ars on i in., 2003). W badaniach polskich $21,8 \%$ osób relacjonowało śmierć osoby najbliższej jako traumę (L i s-Turlejska, 2005). Badania ostatnich lat pokazują, iż trauma wcale nie jest czymś spoza kręgu normalnych przeżyć. Dotyka większość ludzi. Śmierć osoby kochanej to: największe traumatyczne przeżycie (Orwid, 2009), najbardziej stresujący z kryzysów losowych (O le ś, 1992), rodzaj egzystencjalnej traumy (M a m c arz, Popielski, 2008, s. 386).

\subsection{Skutki traumy}

W konsekwencji przeżytej traumy można zaobserwować rozwój zaburzenia po stresie traumatycznym (Post Traumatic Stress Disorder - PTSD). Zgodnie $\mathrm{z}$ teorią kryzysów, im dalej $\mathrm{w}$ stronę patologicznego rozwiązania kryzysu posunął się człowiek, tym trudniej sprowadzić go na drogę zdrowego przepracowania (por. L i s-T u r l e j s k a, Ł u s z c z y ń s k a, 2006). Jednak konsekwencje traumatycznego doświadczenia mogą mieć także charakter rozwojowy. Badania pokazały, iż poczucie zysku wyniesionego z sytuacji trudnej bywa znacznie wyższe od poczucia poniesionych strat (D udek, 2003). Nie każdy jednak potrafi wykorzystać szansę niesioną przez kryzys. Będzie w stanie to zrobić ten, 
kto potrafi afirmować cierpienie (Zdankiewicz-Ś cigała, Przybylska, 2002). Każdy etap kryzysu może być zatem etapem wzrostu, jeśli zostanie pozytywnie przezwyciężony.

\subsection{Potraumatyczny rozwój}

R. G. Tedeschi i L. G. Calhoun wprowadzili termin rozwój (wzrost) potraumatyczny (posttraumatic growth - PTG) dla określenia pozytywnych zmian, pojawiających się $\mathrm{w}$ wyniku podejmowanych prób poradzenia sobie $\mathrm{z}$ następstwami traumatycznego zdarzenia (Tedeschi, Calhoun, 1996). Zjawisko rozwoju po traumie najwyraźniej objawia się w sytuacji poważnego kryzysu, często wraz z nim występują zmiany życiowe, których nie sposób wytłumaczyć iluzjami. W końcu taki wzrost nie jest mechanizmem radzenia sobie, ale jego wynikiem. Zmusza do kluczowej zmiany założeń życiowych, a zdolność jednoczesnego objęcia umysłem strat i wzrostu to przejaw olbrzymiej ludzkiej dojrzałości. Potraumatyczny wzrost nie niweluje dyskomfortu emocjonalnego, ale może prowadzić do pełniejszego poczucia sensu życia, rozwoju duchowego, zauważenia nowych życiowych możliwości, zwiększenia umiejętności radzenia sobie z trudnymi wyzwaniami życia, dojrzalszej filozofii życia i życiowej mądrości, zmian w hierarchii priorytetów, poprawy relacji z ważnymi osobami, przewartościowania znaczeń, zwiększenia polegania na sobie i akceptacji własnej wrażliwości. Zjawisko to jest, jak się okazuje, dość powszechne, co nie oznacza, że uniwersalne. Jego występowanie kształtuje się na poziomie 50-60\% (M a m c arz, Popiels ki, 2008). R. G. Tede s ch i i L. G. Calhoun (2007) twierdzą, iż najwięcej pozytywnych zmian zauważa się w okresie od dwóch tygodni do dwóch miesięcy po traumie. PTG może mieć też miejsce również wiele lat po traumie.

\subsection{Psychologiczne czynniki sprzyjające rozwojowym zmianom po traumie}

Współczesne teorie stresu akcentują, że przeżyta trauma, choćby osobista strata, może przynieść korzystne zmiany w osobowości i funkcjonowaniu człowieka, a warunkiem takich zmian są czynniki związane z osobowością (Aldwin, 1994; Anton ovsky, 1995; Armeli i in., 2001). Jak podkreślają R. C. Carson i in. (2003), im lepiej zintegrowana jest osobowość jednostki, tym większe jej szanse na poradzenie sobie z traumą.

Istotna w tym kontekście wydaje się umiejętność odnajdywania w przeżytych traumach sensu i znaczenia, które prawdopodobnie angażują ten sam proces kreatywny (O gińska-Bulik, 2010). Im wyższe poczucie sensu życia, tym sprawniej osoba obchodzi się z doświadczeniem cierpienia (P o p i e l s k i, 2009). Człowiek doskonale zdaje sobie sprawę $\mathrm{z}$ tego, że sens można spotkać też w sposobie, w jaki znosi cierpienie. Osoba zdrowa to jedność biopsychono- 
etyczna (Popielski, 1994). Zaktywizowana noodynamika pomaga radzić sobie z bólem, cierpieniem, traumą (P u fa l-S tru zi k, 2005; S u c h o ck a i in., 2008; Mróz, 2008). Aktywność noetyczna pomaga w cierpieniu, chroni przed pustką egzystencjalną. Odnajdowanie korzyści w trudnych zdarzeniach jest dość powszechne, występuje u 70-80\% osób, które przeżyły śmierć osoby bliskiej (D a vis, Nolen-H o e k s e ma, 2001). Taka utrata często skutkuje olbrzymim chaosem psychicznym, który paradoksalnie staje się wołaniem o sens (Pop i els ki, 1994). Czerpanie korzyści z dramatycznych zdarzeń jest nieodłącznie związane z rozwojem duchowym osoby (O g iń s k a-B u lik, 2010).

Badania pokazały też, że silna nadzieja podstawowa pomaga w pozytywnym przewartościowaniu i rekonstrukcji traumy tak, by uwolnić się z myślenia o niej w kategoriach przyczynowości osobistej, obwiniania siebie czy losu, pozwala szacować konstruktywność osobowościowych zmian po traumie. „Adaptacyjna rola nadziei podstawowej jest szczególnie znacząca w sytuacji nieodwracalnej straty stawiającej jednostkę przed wyborem nowych alternatyw życiowych. Jednostki żywiące silną nadzieję, że świat jest sensowny i generalnie przychylny, szybciej godzą się ze stratą starego ładu, a tym samym łatwiej przechodzą do fazy konstruowania ładu nowego" (Trzebiński, Zięba, 2003 , s. 5). Nadzieja ta pomaga odnajdować sens traumy (Z dankiewicz-Ś c ig a ła, 2009).

Szansę na PTG zwiększa też poczucie koherencji, choć dane z badań nie są w tym obszarze jednoznaczne (L i n ley, J o s e p h, 2004). Poczucie koherencji jest traktowane jako czynnik wpływający na PTG, przyczynia się do udanego radzenia sobie z przeciwnościami i poznawczego ich przetwarzania (A ld w i n, 1994; O'Le ary, I c k ovi cs, 1995; Te de s c hi, Calh o u n, 1995). Potocznie uważa się, że zaakceptowanie smutnych, nieuniknionych wydarzeń szkodzi człowiekowi. Tak naprawdę jest inaczej. Ludzie o wysokim poziomie poczucia koherencji lepiej radzą sobie z codziennością, stykając się z traumą są bliżsi stwierdzeniu, że nie muszą jej się poddać. Wysoki poziom zmiennej umożliwia patrzenie na świat jako działający na korzyść zdrowia człowieka. W badaniach S. Suominen i in. (2001, za: O g ińs k a-B u li k, J u c zy ń s k i, 2008a) poczucie koherencji pozwalało na przewidywanie subiektywnego stanu zdrowia 4 lata po traumie.

Wyjątkowo ważną rolę w minimalizowaniu nieprzystosowawczych objawów traumy pełni prężność (C o n n o r, 2006). Osoba prężna wykazuje wyższy poziom optymizmu, wewnętrznego spokoju, przejawia większą energię życiową (Fredrickson, 2001), jest otwarta na doświadczenia, ciekawa świata, przejawia wyższe poczucie własnej skuteczności i wartości, angażuje się w relacje z ludźmi (Co n nor, 2006). Korzysta przede wszystkim z przystosowawczych strategii radzenia sobie (O g i ń s k a-B u lik, J u c z y ń s ki, 2008a, b). Prężność wiąże się też $z$ występowaniem pozytywnych emocji i mniejszą skłonnością do korzystania z mechanizmów obronnych, rzadszego zniekształca- 
nia i pomijania informacji, lecz nie oznacza automatycznego powrotu do zdrowia, a dynamiczne dopasowanie się do tragicznych okoliczności (N a d ol $\mathrm{ska}, \mathrm{S} \mathrm{ęk}, 2007)$. Znaczenie prężności dla PTG w żałobie pokazały badania M. Felcyn-K oczewskiej i N. O giński ej-Bulik (2011).

Zatem wystapienie PTG jest efektem współdziałania wielu i różnorodnych czynników zarówno zewnętrznych, jak i podmiotowych, związanych z osobowością jednostki, które $\mathrm{z}$ jednej strony wpływają na zdolność nadawania znaczenia przeżytemu traumatycznemu zdarzeniu, $\mathrm{z}$ drugiej - determinują podejmowane strategie zaradcze (O g i ńs k a-B u lik, 2010).

\section{Cel i metoda badań}

Celem podjętych badań było ustalenie roli czynników psychologicznych, takich jak poczucie koherencji, prężność osobowości, nadzieja podstawowa oraz noodynamika (traktowanych jako zmienne niezależne) w potraumatycznym rozwoju osób w żałobie. Postawiono następujące pytania badawcze.

1. Jaki jest poziom włączonych do badań zmiennych u osób w żałobie?

2. Czy zmienne socjodemograficzne (płeć, wiek, wykształcenie, miejsce zamieszkania, stopień pokrewieństwa ze zmarłym) różnicują nasilenie potraumatycznego rozwoju?

3. Czy istnieje związek między rozwojem potraumatycznym a poczuciem koherencji, prężnością osobowości, nadzieją podstawową i noetycznym jej wymiarem u badanych osób i jaki jest charakter tego związku?

4. Które z wybranych zmiennych niezależnych są predyktorami potraumatycznego rozwoju w badanej grupie osób, które straciły najbliższą osobę?

Badaniami objęto osoby, które w przeciagu dwóch miesięcy poprzedzających badanie straciły osobę bliską. Podczas wstępnej rozmowy - poprzedzającej część kwestionariuszową badania - badani relacjonowali, iż osoba, który zmarła, była dla nich kimś ważnym i kochanym (eliminowano osoby, których stosunek do zmarłego, był obojętny lub wrogi) oraz, iż jego śmierć wywołała u badanych bardzo silne emocje (strach, smutek, bezradność). Taka wstępna selekcja pozwoliła zaprosić do badań tylko te osoby, dla których doświadczona utrata była traumatycznym przeżyciem. W rezultacie do analizy włączono wyniki 101 osób - 53 kobiet i 48 mężczyzn (istotnie starszych od kobiet, $p<0,002$ ). Średnia wieku badanych wynosiła 43,27 lata $(S D=15,59)$, najmłodsza osoba miała 18 lat, najstarsza - 74. Największa część badanych $(44,6 \%)$ posiadała wykształcenie średnie (39,6\% - wyższe, $15,8 \%$ - podstawowe). Dla znaczącego odsetka badanych $(40,6 \%)$ wydarzeniem traumatycznym była utrata jednego z rodziców. Drugą co do liczebności, grupą byli ci, których dotknęła śmierć rodzeństwa, trzecią - śmierć małżonka. Najmniej liczną grupę $(14,8 \%)$ stanowiły osoby borykające się ze śmiercią własnego dziecka. 
W badaniach wykorzystano następujące techniki pomiaru:

- Inwentarz Potraumatycznego Rozwoju, którego autorami są: R. G. Tedeschi i L. G. Calhoun (polska adaptacja N. Ogińska-Bulik i Z. Juczyński). Narzędzie zawiera 21 stwierdzeń. Osoba badana proszona jest o zaznaczenie wydarzenia, które zmieniło jej życie, o wskazanie czasu, jaki od niego upłyną, i stopnia zmian, jakich doświadczyła w wyniku doznanego kryzysu na skali: od „nie doświadczyłem tej zmiany w wyniku kryzysu” (0) do „doświadczyłem tej zmiany w bardzo dużym stopniu" (5). Polska wersja narzędzia ocenia 4 aspekty: zmiany $\mathrm{w}$ percepcji siebie, zmiany $\mathrm{w}$ relacjach $\mathrm{z}$ innymi, większe docenianie życia i zmiany duchowe. Rzetelność narzędzia, oceniana za pomocą współczynnika $\alpha$ Cronbacha, jest wysoka i wynosi dla całej skali 0,93; dla poszczególnych czynników: od 0,87 do 0,63 (O g i ń s k a-B u li k, J u c z y ń s k i, 2010).

- Kwestionariusz do badania poczucia koherencji SOC-29 A. Antonovsky'ego (polska adaptacja J. Koniarek, B. Dudek, Z. Makowska) składa się z 29 pytań i 7-stopniowej skali. Narzędzie mierzy 3 wymiary: poczucie zrozumiałości, zaradności i sensowności. Wartości normatywne wskazane przez autora to 133-160 pkt. Im wyższy wynik, tym silniejsze poczucie koherencji. Badania dowodzą, że kwestionariusz charakteryzuje się wysoką rzetelnością i trafnością (Ko ni arek i in., 1993).

- Skala Prężności SPP-25 - autorstwa N. Ogińskiej-Bulik i Z. Juczyńskiego - zawiera 25 pozycji. Osoba badana dysponuje skalą: od „zdecydowanie nie” (0) do „zdecydowanie tak” (4). Zakres wyników to 0-100 pkt. Im wyższy wynik, tym większy poziom prężności. Skala pozwala na uzyskanie wyniku ogólnego oraz wyników pięciu czynników. Rzetelność dla całej skali wynosi 0,89, a stabilność bezwzględna $=0,85$ (O g iń s k a-B u li k, J u c z y ń s k i, 2008b).

- Kwestionariusz Nadziei Podstawowej BHI-12 J. Trzebińskiego i M. Zięby - narzędzie samoopisowe, składające się z 12 twierdzeń. Badany określa każdorazowo, $\mathrm{w}$ jakim stopniu zgadza się $\mathrm{z}$ poszczególnymi twierdzeniami na skali: od „zdecydowanie nie zgadzam się” do „zdecydowanie zgadzam się”. Trzy pozycje mają charakter buforowy. Zakres możliwych do uzyskania wyników wynosi od 9 do 45 pkt. Im wyższy wynik, tym większa nadzieja podstawowa. Autorzy określają trafność i rzetelność narzędzia jako satysfakcjonujące (Trze biński, Zi ę ba, 2003).

- Test noodynamiki T.N-D K. Popielskiego, który składa się ze 100 itemów i czterech skal. Na pytania osoba badana odpowiada na 5-stopniowej skali: od „bardzo często” (5) do „nigdy” (1). Skala pozwala uzyskać trzy rodzaje wyników ze względu na potrzeby badacza: wynik ogólny, poszczególnych części i w poszczególnych skalach. Test zawiera 4 kategorie, w które wchodzi 36 skal: jakości noetyczne (skale 1-14), temporalność noetyczna (skale 15-17), aktywność noetyczna (skale 18-30) i postawy noetyczne (skale 31-36) (P o p i e ls ki, 1994). 


\section{Wyniki badań}

W badanej grupie średni ogólny wynik w zakresie potraumatycznego rozwoju wyniósł $60,54(S D=21,15)$, a dla poszczególnych kolejnych czynników: $23,26(S D=10,25), 22,33(S D=7,09), 9,83(S D=3,41)$ i $5,13(S D=3,08)$. Zatem zgodnie z normami (O g ińs k a-B u lik, J u c zy ński, 2010) można go uznać za przeciętny (piąty sten). 27,7\% badanych uzyskało niskie wyniki w zakresie rozwoju po traumie, $38,6 \%$ - przeciętne, $33,7 \%$ - wysokie. Analiza uzyskanych wyników wskazała, że wiek, płeć, miejsce zamieszkania, wykształcenie ani stopień pokrewieństwa ze zmarłym uczestników badania nie różnicują w sposób istotny statystycznie poziomu potraumatycznego rozwoju.

Średni wynik prężności w badanej grupie wyniósł $68,06(S D=13,98)$ i jest on nieznacznie niższy od uzyskanego w badaniach osób w żałobie przeprowadzonych przez N. O gińs ką-B u lik i Z. J u c zyńskie go (2008b). Z kolei średni wynik w zakresie nadziei podstawowej osiagnął wartość 30,09 $(S D=$ 6,20) i zgodnie z normami (Trzebiński, Zięba, 2003) jest przeciętny. Średni wynik ogólny poczucia koherencji w grupie wyniósł 133,79 $(S D=25,55)$ i mieści się w zakresie wartości normatywnych wskazanych przez A. Antonovsky'ego (1995). Średni przeliczony wynik w zakresie noodynamiki wyniósł 3,65, zatem jest niższy od uzyskanego w badaniach K. P o p i e l s k i e g o (1994), gdzie $M=4,49(S D=0,59)$.

Następnie ustalono zależności między potraumatycznym rozwojem i jego czynnikami a zmiennymi niezależnymi. Współczynniki korelacji pokazały istotny statystycznie związek między PTG a wszystkimi zmiennymi niezależnymi - najsilniejszy dotyczył prężności i poczucia koherencji. Wyniki przedstawiono w tab. 1.

W kolejnym kroku sprawdzono, czy poziom zmiennych niezależnych różnicuje nasilenie pozytywnych zmian po traumie. Grupę badana na podstawie górnego i dolnego kwartyla ogólnego wyniku prężności podzielono na tych o wysokim i niskim nasileniu zmiennej. Analizy statystyczne pokazały bardzo istotne różnice $\mathrm{w}$ nasileniu PTG i jego czynników w zależności od niskiego i wysokiego nasilenia prężności (tab. 2).

Prężność to umiejętność odrywania się od trudnych doświadczeń życiowych, patrzenia na nie $\mathrm{z}$ dystansu, czerpania $\mathrm{z}$ nich. W grupie osób badanych o wysokiej prężności potraumatyczny wzrost osiaga wyraźnie wyższy poziom. Podobną zależność można stwierdzić, przyglądając się natężeniu jego poszczególnych czynników. Zatem u osób, u których obserwuje się spójność i wytrwałość w przystosowywaniu się do wydarzeń życiowych, pewność siebie, otwartość na nowe doświadczenia, umiejętność tolerowania trudnych emocji i wewnętrznego spokoju, pozwalające znosić trudy życia i traktować je jako wyzwania, można spodziewać się wystąpienia pozytywnych zmian w wyniku traumy. 
Współczynniki korelacji między zmiennymi niezależnymi a potraumatycznym rozwojem

\begin{tabular}{|c|c|c|c|c|c|}
\hline & \begin{tabular}{|c} 
Potrau- \\
matyczny \\
rozwój - \\
wynik ogólny
\end{tabular} & $\begin{array}{l}\text { Czynnik 1: } \\
\text { zmiany } \\
\text { w percepcji } \\
\text { siebie }\end{array}$ & $\begin{array}{l}\text { Czynnik 2: } \\
\text { zmiany } \\
\text { w relacjach } \\
\text { z innymi }\end{array}$ & $\begin{array}{l}\text { Czynnik 3: } \\
\text { większe } \\
\text { docenianie } \\
\text { życia }\end{array}$ & $\begin{array}{l}\text { Czynnik 4: } \\
\text { zmiany } \\
\text { duchowe }\end{array}$ \\
\hline Prężność - wynik ogólny & $0,57 * * *$ & $0,60 * * *$ & $0,53 * * *$ & $0,28 * *$ & $0,42 * * *$ \\
\hline $\begin{array}{l}\text { Czynnik 1: wytrwałość i de- } \\
\text { terminacja w działaniu }\end{array}$ & $0,61 * * *$ & $0,56 * * *$ & $0,64 * * *$ & $0,33 * * *$ & $0,48 * * *$ \\
\hline $\begin{array}{l}\text { Czynnik 2: otwartość na nowe } \\
\text { doświadczenia i poczucie } \\
\text { humoru }\end{array}$ & $0,31 * *$ & $0,34 * * *$ & $0,27 * *$ & 0,12 & $0,24 *$ \\
\hline $\begin{array}{l}\text { Czynnik 3: kompetencje oso- } \\
\text { biste do radzenia sobie i to- } \\
\text { lerancja negatywnych emocji }\end{array}$ & $0,51 * * *$ & $0,55 * * *$ & $0,46^{* * *}$ & $0,25^{*}$ & $0,30 * *$ \\
\hline $\begin{array}{l}\text { Czynnik 4: tolerancja na nie- } \\
\text { powodzenia i traktowanie } \\
\text { życia jako wyzwania }\end{array}$ & $0,55^{* * *}$ & $0,58 * * *$ & $0,50 * * *$ & $0,29 * *$ & $0,39 * * *$ \\
\hline $\begin{array}{l}\text { Czynnik 5: optymistyczne } \\
\text { nastawienie do życia i zdol- } \\
\text { ność mobilizowania się } \\
\text { w trudnych sytuacjach }\end{array}$ & $0,49 * * *$ & $0,54 * * *$ & $0,41 * * *$ & $0,21 *$ & $0,41 * * *$ \\
\hline Nadzieja podstawowa & $0,48^{* * *}$ & $0,47 * * *$ & $0,48 * * *$ & $0,28 * *$ & $0,30 * *$ \\
\hline $\begin{array}{l}\text { Poczucie koherencji - wynik } \\
\text { ogólny }\end{array}$ & $0,66^{* * *}$ & $0,60 * * *$ & $0,66^{* * *}$ & $0,48 * * *$ & $0,49 * * *$ \\
\hline Poczucie zrozumiałości & $0,59 * * *$ & $0,55 * * *$ & $0,57 * * *$ & $0,44 * * *$ & $0,43 * * *$ \\
\hline Poczucie zaradności & $0,57 * * *$ & $0,49 * * *$ & $0,62 * * *$ & $0,37 * * *$ & $0,46^{* * *}$ \\
\hline Poczucie sensowności & $0,68 * * *$ & $0,61 * * *$ & $0,67 * * *$ & $0,55 * * *$ & $0,49 * * *$ \\
\hline Noodynamika - wynik ogólny & $0,46 * * *$ & $0,42 * * *$ & $0,51 * * *$ & $0,25^{*}$ & $0,30 * *$ \\
\hline Jakości noetyczne & $0,51 * * *$ & $0,46 * * *$ & $0,56 * * *$ & $0,29 * *$ & $0,36^{* * *}$ \\
\hline Aktywność noetyczna & $0,43 * * *$ & $0,40 * * *$ & $0,48 * * *$ & $0,24 *$ & $0,28 * *$ \\
\hline Postawy noetyczne & $0,25 *$ & $0,23 *$ & $0,30 * *$ & 0,10 & 0,12 \\
\hline
\end{tabular}

$$
{ }^{*} p \leq 0,05 ; * * p \leq 0,01 ; * * * p \leq 0,001 \text {. }
$$


Nasilenie pozytywnych zmian po traumie w zależności od poziomu prężności

\begin{tabular}{|l|c|c|c|c|c|c|}
\cline { 2 - 7 } \multicolumn{1}{c|}{} & \multicolumn{2}{c|}{$\begin{array}{c}\text { Prężność wysoka } \\
(n=23)\end{array}$} & \multicolumn{2}{c|}{$\begin{array}{c}\text { Prężność niska } \\
(n=22)\end{array}$} & \multicolumn{2}{c|}{$\begin{array}{c}\text { Test } U \\
\text { Manna-Whitneya }\end{array}$} \\
\cline { 2 - 7 } \multicolumn{1}{c|}{} & $M$ & $S D$ & $M$ & $S D$ & $Z$ & $p$ \\
\hline $\begin{array}{c}\text { Potraumatyczny rozwój - wynik } \\
\text { ogólny }\end{array}$ & 80,04 & 14,90 & 46,50 & 23,51 & 4,43 & $0,001^{* * *}$ \\
\hline $\begin{array}{l}\text { Czynnik 1: zmiany w percepcji } \\
\text { siebie }\end{array}$ & 33,52 & 6,71 & 16,23 & 11,17 & 4,54 & $0,001^{* * *}$ \\
\hline $\begin{array}{l}\text { Czynnik 2: zmiany w relacjach z } \\
\text { innymi }\end{array}$ & 27,78 & 4,80 & 17,41 & 8,61 & 3,89 & $0,001^{* * *}$ \\
\hline $\begin{array}{l}\text { Czynnik 3: większe docenianie } \\
\text { życia }\end{array}$ & 11,70 & 2,75 & 9,36 & 3,42 & 2,27 & $0,05^{*}$ \\
\hline Czynnik 4: zmiany duchowe & 7,04 & 2,69 & 3,50 & 2,74 & 3,50 & $0,001^{* * *}$ \\
\hline
\end{tabular}

$M$ - średnia, $S D$ - odchylenie standardowe; ${ }^{*} p \leq 0,05 ;{ }^{* *} p \leq 0,01 ; * * * p \leq 0,001 ; Z$ - wartość statystyki.

Porównanie osób o wysokim i niskim nasileniu nadziei podstawowej pokazało, iż grupy te istotnie statystycznie różnią się pod kątem nasilenia potraumatycznego rozwoju - wyniku ogólnego oraz dwóch pierwszych czynników PTG (tab. 3).

T a b e la 3

Nasilenie pozytywnych zmian po traumie w zależności od poziomu nadziei podstawowej

\begin{tabular}{|l|c|c|c|c|c|c|}
\hline \multirow{2}{*}{ Potraumatyczny rozwój } & \multicolumn{2}{|c|}{$\begin{array}{c}\text { Nadzieja niska } \\
(n=22)\end{array}$} & \multicolumn{2}{c|}{$\begin{array}{c}\text { Nadzieja wysoka } \\
(n=22\end{array}$} & \multicolumn{2}{c|}{$\begin{array}{c}\text { Test } U \text { Manna- } \\
\text { Whitneya }\end{array}$} \\
\cline { 2 - 7 } & $M$ & $S D$ & $M$ & $S D$ & $Z$ & $p$ \\
\hline $\begin{array}{c}\text { Potraumatyczny rozwój - } \\
\text { wynik ogólny }\end{array}$ & 67,50 & 27,16 & 45,27 & 19,50 & 2,66 & $0,01^{* *}$ \\
\hline $\begin{array}{l}\text { Czynnik 1: zmiany w percep- } \\
\text { cji siebie }\end{array}$ & 27,27 & 13,10 & 15,77 & 9,22 & 2,84 & $0,01^{* *}$ \\
\hline $\begin{array}{l}\text { Czynnik 2: zmiany w rela- } \\
\text { cjach z innymi }\end{array}$ & 24,36 & 7,61 & 17,32 & 7,97 & 3,29 & $0,001^{* * *}$ \\
\hline $\begin{array}{c}\text { Czynnik 3: większe docenia- } \\
\text { nie życia }\end{array}$ & 10,05 & 4,31 & 8,18 & 2,81 & 1,54 & 0,124 ni \\
\hline Czynnik 4: zmiany duchowe & 5,82 & 3,55 & 4,00 & 2,69 & 1,87 & 0,062 ni \\
\hline
\end{tabular}

Oznaczenia: jak w tab. 2, ni - nieistotne. 
Nadzieja podstawowa zwiększa w sytuacji trudnej gotowość do budowania nowego ładu (Trzebiński, Zi ęb a, 2003). Nadzieja podstawowa w sytuacji nieodwracalnej straty wiąże się z nieangażowaniem się w coś, czego nie można zmienić. Może to być związane z pewnego rodzaju zawierzeniem siebie i życiowego porządku losowi, boskiej sile. Stąd osoby o wysokiej sile konstruktu moga jednocześnie doświadczać wzrostu religijności, rozumienia spraw duchowych - wiara $\mathrm{w}$ ich ład może pomagać $\mathrm{w}$ radzeniu sobie $\mathrm{z}$ traumą. Jednak nie oznacza to, iż jest ona bodźcem, dzięki któremu bardziej szanują życie.

Test $U$ Manna-Whitneya pokazał silne statystyczne różnice $(p<0,000)$ w nasileniu potraumatycznego rozwoju i wszystkich jego czynników w zależności od nasilenia poczucia koherencji. $\mathrm{W}$ tab. 4 pokazano wyraźnie wyższe wyniki w zakresie wszystkich czynników potraumatycznego rozwoju u osób o wysokim nasileniu poczucia koherencji.

T a b e l a 4

Nasilenie pozytywnych zmian po traumie w zależności od poziomu poczucia koherencji

\begin{tabular}{|l|r|r|r|r|c|c|c|}
\hline \multirow{2}{*}{ Potraumatyczny rozwój } & \multicolumn{2}{|c|}{$\begin{array}{c}\text { Koherencja } \\
\text { wysoka }(n=24)\end{array}$} & \multicolumn{2}{c|}{$\begin{array}{c}\text { Koherencja } \\
\text { niska }(n=25)\end{array}$} & \multicolumn{2}{c|}{$\begin{array}{c}\text { Test } U \\
\text { Manna-Whitneya }\end{array}$} \\
\cline { 2 - 9 } & $M$ & $S D$ & $M$ & $S D$ & $Z$ & $p$ \\
\hline Potraumatyczny rozwój - wynik ogólny & 78,96 & 14,70 & 42,88 & 19,76 & 4,97 & $0,000 * * *$ \\
\hline Czynnik 1: zmiany w percepcji siebie & 30,96 & 9,18 & 15,76 & 9,93 & 4,49 & $0,000^{* * *}$ \\
\hline Czynnik 2: zmiany w relacjach z innymi & 28,33 & 3,29 & 16,20 & 6,80 & 4,96 & $0,000^{* * *}$ \\
\hline Czynnik 3: większe docenianie życia & 12,63 & 1,64 & 8,00 & 3,21 & 4,54 & $0,000^{* * *}$ \\
\hline Czynnik 4: zmiany duchowe & 7,04 & 2,14 & 2,92 & 2,33 & 4,74 & $0,000^{* * *}$ \\
\hline
\end{tabular}

Oznaczenia: jak w tab. 2.

Można wnioskować, iż wszystkie wymiary konstruktu pełnią znaczącą rolę $\mathrm{w}$ pozytywnych zmianach w efekcie traumy. Istotny związek zauważyć można zarówno z poczuciem zrozumienia wydarzeń niesionych przez życie, przekonaniem, iż mimo bolesności mają one sens i że warto angażować się w radzenie sobie z nimi, wykorzystując zasoby własne i pochodzące od innych bliskich osób. Osoby o silnych tego typu przekonaniach wyróżniają się zdecydowanie większymi zdolnościami w czerpaniu pozytywów z traumatycznej utraty osoby bliskiej we wszystkich czterech obszarach.

Kolejny krok analiz pokazał, iż nasilenie noodynamiki istotnie wiąże się z poziomem wyniku ogólnego i wszystkich czynników PTG (w przypadku czynnika trzeciego jest to zależność na poziomie tendencji), a najsilniejszy związek $\mathrm{z}$ natężeniem noodynamiki cechuje czynnik: zmiany $\mathrm{w}$ relacjach $\mathrm{z}$ innymi (tab. 5). 
Nasilenie pozytywnych zmian po traumie w zależności od poziomu noodynamiki

\begin{tabular}{|l|c|c|c|c|c|c|}
\hline \multirow{2}{*}{ Potraumatyczny rozwój } & \multicolumn{2}{|c|}{$\begin{array}{c}\text { Noodynamika } \\
\text { wysoka }\end{array}$} & \multicolumn{2}{c|}{$\begin{array}{c}\text { Noodynamika } \\
\text { niska }(n=25)\end{array}$} & \multicolumn{2}{c|}{ Test $U$} \\
Manna-Whitneya
\end{tabular}

Oznaczenia: jak w tab. 2, ni - nieistotne.

Wyniki te wskazują, iż badana grupa osób zauważa i ceni obecność innych osób wokół siebie oraz ocenia swoje relacje z nimi jako dobre. W następnej kolejności najsilniejszy związek noodynamiki zanotowano z wymiarem zmiany $\mathrm{w}$ percepcji siebie $(p<0,006)$. Osoby badane potrafią czerpać z życiowych doświadczeń, potrafią w sytuacji cierpienia uchronić się przed pustką egzystencjalną. To wszystko wiąże się z pewnością z poczuciem wzrostu siły osobistej. Jak zilustrowano w tab. 5, osoby o wysokiej noodynamice uzyskują widocznie wyższe wyniki w zakresie wszystkich czynników wzrostu po traumie. Człowiek porzebuje dynamiki duchowej - noodynamiki. Szczególnie wtedy, gdy staje wobec trudnych życiowych zadań, wobec cierpienia. Dla Ja ból traumy może być zagrażający. Jednak sens życia uobecnia się najwyraźniej właśnie wtedy, a cierpienie zyskuje wówczas moc kreowania, rozwoju. U osób o zaktywizowanej noodynamice można obserwować rozwojowe zmiany mimo rozpaczy, szoku, tęsknoty.

Końcowy etap analizy wyników wiązał się z ustaleniem wyznaczników rozwoju potraumatycznego. W tym celu wykorzystano analizę regresji (wersja krokowa postępująca), a wyniki zamieszczono w tab. 6 .

Zatem wzrost po traumie warunkuje: wytrwałość i determinacja w działaniu - czynnik prężności $(\beta=0,31)$ i poczucie sensowności - wymiar poczucia koherencji $(\beta=0,45)$. Zmienne te mają istotne znaczenie w wyjaśnianiu wzrostu po traumatycznej utracie bliskiej osoby. Wprost proporcjonalna zależność między pierwszym czynnikiem prężności a PTG wskazuje, iż wytrwałość i determinacja $\mathrm{w}$ działaniu sprzyja rozwojowi po traumie $(\beta=0,31)$. Zatem osoby, które mimo trudnych sytuacji odznaczają się determinacją i zdecydowaniem w podejmowaniu swoich działań, swoistą pewnością siebie i przekonaniem, że to co czynią, jest słuszne, potrafią czerpać większe korzyści z traumy. 
Wyznaczniki potraumatycznego rozwoju (wynik ogólny)

\begin{tabular}{|l|c|c|c|c|c|c|}
\hline \multicolumn{1}{|c|}{ Zmienna } & $\beta$ & $\begin{array}{c}\text { Błąd } \\
\text { standardowy } \\
\beta\end{array}$ & $B$ & $\begin{array}{c}\text { Błąd } \\
\text { standardowy } \\
B\end{array}$ & $t$ & $p$ \\
\hline Wyraz wolny & - & - & $-14,82$ & 7,98 & $-1,86$ & 0,066 \\
\hline $\begin{array}{l}\text { Prężność - czynnik 1: } \\
\text { wytrwałość i determina- } \\
\text { cja w działaniu }\end{array}$ & 0,31 & 0,08 & 1,94 & 0,53 & 3,68 & $0,000 * * *$ \\
\hline Poczucie sensowności & 0,45 & 0,08 & 1,18 & 0,22 & 5,38 & $0,000 * * *$ \\
\hline \multicolumn{7}{|l}{$R=0,69 ; R^{2}=0,48 ; F_{(2,98)}=46,66 ; p<0,000$} \\
\hline
\end{tabular}

$R$ - współczynnik korelacji wielokrotnej,

$R^{2}$ - współczynnik wielokrotnej determinacji,
$F ; p-$ istotność równania

$t$ - test $t$-Studenta

Analiza regresji wykazała, iż osoby o silnym przekonaniu, co do sensowości tego, co je spotyka i własnych działań $(\beta=0,45)$ czerpią więcej pozytywnych zmian z traumy. Wierza, że to, co im się przydarza ma swój sens, co może być pomocne w zmianach wzrostowych po bolesnym zdarzeniu. Uzyskane wyniki pozwalają stwierdzić, iż w przypadku zdarzenia tak druzgocącego i pozostającego poza kontrolą jednostki, które jednocześnie trudno objąć zdrowym rozsądkiem, to wiara w wyższy, często trudny do zrozumienia, sens tego, co niesie życie, wiąże się z czerpaniem korzyści z traumy. Z analizy współczynnika korelacji wynika, iż analizowane zmienne są silnie ze sobą powiązane $(R=$ $0,69)$. Czynnik pierwszy prężności i poczucie sensowności wyjaśniają rozwój po traumie, thumacząc $48 \%$ wariancji $\left(R^{2}=0,48\right)$.

Jeśli chodzi o pierwszy czynnik potraumatycznego wzrostu - zmiany w percepcji siebie - okazuje się, że jest on warunkowany tymi samymi, co wynik ogólny PTG, zmiennymi. W przypadku obu zależność jest wprost proporcjonalna - im większa wytrwałość i determinacja w działaniu $(\beta=0,31)$ i im większe poczucie sensowności $(\beta=0,42)$, tym wyższe wyniki w zakresie pierwszego czynnika rozwoju po traumie. Wspomniane zmienne thumaczą $42 \%$ wariancji zmiennej zależnej $\left(R^{2}=0,42\right)$. Wyznacznikami czynnika drugiego PTG ponownie okazały się te same dwie zmienne, które wyjaśniają 52\% wariancji zmiennej zależnej $\left(R^{2}=0,52\right)$. Predyktorem większego doceniania życia - trzeciego czynnika PTG - okazało się tylko poczucie sensowności $(\beta=0,55)$, które wyjaśnia wzrost szacunku do życia, tłumacząc $30 \%$ wariancji $\left(R^{2}=0,30\right)$. Predyktorami zmian duchowych - ostatniego czynnika PTG - są: poczucie zaradności oraz otwartość - wymiar skali jakości noetycznych, które łącznie wyjaśniają 29\% wariancji zmiennej zależnej $\left(R^{2}=0,29\right)$. 


\section{Podsumowanie}

Mimo iż przeprowadzone badania są badaniami korelacyjnymi, przekrojowymi (co wiąże się z oczywistymi ograniczeniami), uzyskane wyniki, przeprowadzone na grupie osób w żałobie, wskazują, iż istnieją zmienne osobowościowe, które współwystępują w sposób istotny ze zjawiskiem potraumatycznego rozwoju. Są to: poczucie koherencji, nadzieja podstawowa, prężność i noodynamika. Zjawisko wzrostu po traumatycznej utracie można wyjaśnić na podstawie znajomości wyników w zakresie zmiennych psychologicznych, stanowiących jego predyktory. Czynnikami wyjaśniającymi są: wytrwałość i determinacja w działaniu (pierwszy czynnik prężności), poczucie sensowności i zaradności (wymiary poczucia koherencji) i otwartość (wymiar jakości noetycznych). W przypadku wymienionyh wyznaczników potraumatycznego rozwoju i jego czynników, zależność jest wprost proporcjonalna - im wyższe natężenie wyżej wspomnianych zmiennych osobowościowych, tym więcej zmian wzrostowych w efekcie traumy.

Osoby czerpiące korzyści z traumy nie tylko ujawniają twardość, która to właściwość osobowości prowadzi do rozwoju prężności, ale i tolerują trudne doświadczenie, pozwalając je sobie przeżyć. Jest to spójne ze stwierdzeniem R. T e d e s ch i e g o i L. Ca l h o u n a (1995), iż rozwój taki istnieje nie zamiast, ale obok rozpaczy i poczucia straty. Wyniki te zgodne są z doniesieniami z innych badań, które wskazują, iż prężność jest powiązana z PTG (C o n n or, 2006; Ogińska-Bulik，2010; O gińska-Bulik，Juczyński，2008a; Felcyn-Koczewska, Ogińska-Bulik, 2011). Dodatkowo nadzieja podstawowa zwiększa w sytuacji trudnej gotowość budowania nowego ładu (Trzebiński, Zięba, 2003). Badania pokazują, iż na fundamencie takiej mobilizacji łatwiej dostrzegać nowe możliwości życiowe. Prezentowane w literaturze wyniki badań dotyczące związku poczucia koherencji z PTG nie są jednoznaczne (Ogińska-Bulik, Juczyński, 2010). Uzyskane wyniki wydają się spójne $\mathrm{z}$ tymi, które podkreślają wzmacniającą rolę poczucia koherencji $\mathrm{w}$ radzeniu sobie $\mathrm{z}$ trudnymi wydarzeniami życiowymi. Pokazuja, iż wysoki poziom konstruktu obniża poziom doświadczanego stresu (Dudek, Koniarek, 1996) i odgrywa ważną rolę w zapobieganiu pojawienia się objawów stresu pourazowego (D udek, 2003). Można też wnioskować, iż wszystkie wymiary konstruktu pełnią znaczącą rolę w pozytywnych zmianach w efekcie traumy. Wyniki przeprowadzonych badań pokazują, iż osoby o zaktywizowanej noodynamice potrafią czerpać korzyści z trudnego wydarzenia, jakim jest utrata osoby ważnej mimo bólu, szoku, tęsknoty. Zdaniem K. P opie 1ski ego $(1994,2009)$ poczucie sensu życia należy rozumieć jako coś, co po prostu jest. Niektórzy potrafią z niego korzystać nawet, gdy wydaje się, że świat rozpadł się na kawałki. 


\section{Bibliografia}

A $1 \mathrm{~d}$ w i n C. M. (1994), Stress, Coping, and Development, Guilford Press, New York.

Antonovsky A. (1995), Rozwiktanie tajemnicy zdrowia. Jak radzić sobie ze stresem i nie zachorować, Wydawnictwo Fundacja IPN, Warszawa.

A rmeli S., Gunther K. C., Cohe n L. H. (2001), Stressor appraisals, coping and postevent outcomes: the dimensionality and antecedents of stress-related growth, ,Journal of Social and Clinical Psychology", 20, 366-395.

Cars on R. C., Butcher J. N., Minek a S. (2003), Psychologia zaburzeń, vol. 1, GWP, Gdańsk.

Co n n or K. M. (2006), Assessment of resilience in the aftermath trauma, „Journal of Clinical Psychiatry", 67 (2), 46-49.

$\mathrm{D}$ a v i s C. G., N o l e n-H o e k s e m a S. (2001), Loss and meaning: How do people make sense of loss?, „American Behavioral Scientist”, 44, 726-741.

D u d e k B. (2003), Zaburzenie po stresie traumatycznym, GWP, Gdańsk.

D u d e k B., K o n i r e k J. (1996), Social support as a buffer in the stress - burnout relationship, ,International Journal of Stress Management”, 3 (2), 99-106.

E 1 klit A. (2002), Victimization and PTSD in a Danish National Youth Probability Sample, „Journal of the American Academy of Child and Adolescent Psychiatry”, 41 (2), 174-181.

Fe lc yn-Ko c zewska M., O gińska-B ulik N. (2011), Rola prężności w potraumatycznym rozwoju osób w żałobie, [w:] L. G o l i ń s k a, E. B i e l a w s k a-B a t o r o w i c z (red.), Rodzina i praca w warunkach kryzysu, Wydawnictwo UŁ, Łódź, 11-524.

Fre d ri c ks o n B. (2001), The role of positive emotions in positive psychology: The broadenand build theory of positive emotions, „American Psychologist”, 56, 218-226.

Koniarek J., Dudek B., Makowska Z. (1993), Kwestionariusz Orientacji Życiowej. Adaptacja the Sense of Coherence Questionnaire (SOC) A. Antonovsky'ego, „Przegląd Psychologiczny", XXXVI (4), 491-502.

L in 1 e y P. A., J o s e p h S. (2004), Positive change following trauma and adversity, „Psychological Inquiry", 15, 65-69.

L i s-T u rlejska M. (2005), Traumatyczne zdarzenia $i$ ich skutki psychiczne, Wydawnictwo Instytutu Psychologii PAN, Warszawa.

L i s-T u r le j sk a M., Łu s z c zy ń ska A. (2006), Terapia potraumatyczna, [w:] L. Grze s i u k (red.), Psychoterapia. Praktyka. Podręcznik akademicki, ENETEIA, Warszawa, 453466.

Mamcarz P., Popielski K. (2008), Trauma egzystencjalna - próba konceptualizacji, [w:] K. P o p i e $1 \mathrm{~s}$ k i (red.), Wartości dla życia, Wydawnictwo KUL, Lublin, 383-413.

M ró z A. (2008), Rozwój osobowy człowieka, Wydawnictwo KUL, Lublin.

N a d o $1 \mathrm{~s} \mathrm{k} \mathrm{a} \mathrm{K.,} \mathrm{S} \mathrm{ę} \mathrm{k} \mathrm{H.} \mathrm{(2007),} \mathrm{Społeczny} \mathrm{kontekst} \mathrm{odkrywania} \mathrm{wiedzy} \mathrm{o} \mathrm{zasobach} \mathrm{odporno-}$ ściowych, [w:] K a c z m a re k Ł., Sły s z A. (red.), Blizej serca. Zdrowie i emocje, Wydawnictwo Naukowe UAM, Poznań, 13-37.

Ogińska-Bulik N. (2010), Pozytywne zmiany $w$ następstwie doświadczonej traumy zjawisko potraumatycznego rozwoju, [w:] L. S u c h o c k a, R. S z t e m b i s (red.), Człowiek i dzieto, Wydawnictwo KUL, Lublin, 193-203.

O g ińs k a -B u 1 i k N., J u c z y ński Z. (2008a), Osobowość, stres a zdrowie, Wydawnictwo Difin, Warszawa.

O g i ń s k a-B u l i k N., J u c z y ń s k i Z. (2008b), Skala Pomiaru Prężności (SPP-25), „Nowiny Psychologiczne", 3, 39-56.

O gińska-B u lik N., J u c zy ński Z. (2010), Rozwój potraumatyczny - charakterystyka i pomiar, „Psychiatria”, 7 (4), 129-142. 
O’L e a ry V. E., I c k ovi c s J. R. (1995), Resilience and thriving in response to challenge: An opportunity for a paradigm shift in women's health, „Women's Health: Research on Gender, Behavior, and Policy", 1, 121-142.

O 1 e ś P. (1992), Zjawisko kryzysu psychicznego, „Wykłady z Psychologii w KUL”, 6, 367-422.

O r w i d M. (2009), Trauma, Wydawnictwo Literackie, Kraków.

P o p i e 1 s k i K. (1994), Noetyczny wymiar osobowości, Wydawnictwo KUL, Lublin.

P o p i e l s k i K. (2009), Psychologia egzystencji. Wartości w życiu, Wydawnictwo KUL, Lublin.

P u f a l-S t r u z i k R. (2005), Przejawy aktywności noetycznej kobiet w obliczu choroby, Annales, Universitatis Mariae Curie-Skłodowska, LX, SUPPL. XVI, 432, 422-425.

S uchocka L., B ownik I., Popielski K. (2008), Ocena doznań bólowych osób ze schorzeniami reumatycznymi, [w:] K. P o p i e $1 \mathrm{~s} \mathrm{k}$ i (red.), Wartości dla życia, Wydawnictwo KUL, Lublin, 415-431.

Tedeschi R. G., Calhoun L. G. (1995), Trauma and transformation: Growing in the aftermath of suffering, Sage, Thousand Oaks (CA).

T e d e s c h i R. G., C a 1 h o u n L. G. (1996), The Post-Traumatic Growth Inventory: Measuring the positive legacy of trauma, ,Journal of Traumatic Stress”, 9 (3), 455-471.

T e d e s c h i R. G., C a l h o u n L. G. (2007), Podejście kliniczne do wzrostu po doświadczeniach traumatycznych, [w:] P. A. L i n l e y, S. J o s e p h (red.), Psychologia pozytywna w praktyce, Wydawnictwo Naukowe PWN, Warszawa, 230-248.

Trze bińs ki J., Z i ę b a M. (2003), Kwestionariusz nadziei podstawowej-BHI-12. Podręcznik, Pracownia Testów Psychologicznych PTP, Warszawa.

Z d a n k i e w i c z-Ś c i g a ła E. (2009), Nadzieja podstawowa jako moderator procesu adaptacji po traumie, [w:] J. S tre la u, B. Z a w a d z ki, M. K a c z mare k (red.), Konsekwencje psychiczne traumy. Uwarunkowania i terapia, Wydawnictwo Naukowe SCHOLAR, Warszawa, 132-153.

Zdankiewicz-Ścigała, E., Przybylska M. (2002), Trauma. Proces $i$ diagnoza. Mechanizmy psychoneurofizjologiczne, Wydawnictwo Instytutu Psychologii PAN, Szkoła Wyższa Psychologii Społecznej, Warszawa.

Magdalena Felcyn-Koczewska, Nina Ogińska-Bulik

\section{Psychologic Factors Fostering Posttraumatic Growth among People in Mourning}

The term posttraumatic growth was introduced by Tedeschi and Calhun to identify the positive changes occurring as a result of coping with consequences of a traumatic event.

The purpose of the research presented in this article was to establish the role of psychological factors such as sense of coherence, personality resiliency, basic hope and noodynamics in posttraumatic growth among people in mourning. 101 subjects (48 men and 53 women), who experienced loss of a close person within two months prior to the test, participated in the study. Their mean age was $43,27(S D=15,59)$.

The study revealed that there is a relationship between the variables included in the study and level of posttraumatic growth. First factor of resiliency and meaningfulness had emerged to be the predictors of posttraumatic growth - the higher the levels of these variables the higher benefits from trauma are observed in case of people in mourning.

Keywords: posttraumatic growth, trauma, death, mourning (potraumatyczny rozwój, trauma, śmierć, żałoba). 